\title{
An Empirical Study of the Citizen's Perception of Automation Process of Government in India Through E-Governance.
}

\author{
Dr. M.S.Bhat ${ }^{1}$, Dr. Piyush Gupta ${ }^{2}$ and Maj.Gen. (retd.) Dr. R.K.Bagga ${ }^{3}$ \\ ${ }^{1}$ CVR College of Engineering, Department of EIE, Hyderabad, India \\ bhatms@rediffmail.com \\ ${ }^{2}$ Senior General Manager, National Institute of Smart Governance, Hyderabad \\ piyush.gupta@nisg.org \\ ${ }^{3}$ Advisor, Outreach Division, IIIT, Hyderabad \\ rbagga@iiit.ac.in
}

\begin{abstract}
E governance has brought in considerable benefits both to citizens and the administration. From the administration point of view, many routine aspects of administration categorized as programmable work can be computerized thereby increasing efficiency and reducing cost. From the citizen's point of view, e governance would mean automation and standardization of government service delivery thereby eliminating red tape. The reduction in frequency of human interfacing can be an important benefit from the perspective of citizen, as it could minimize delays and chances of corruption. $E$ governance can indeed be very successful if citizen's perception of the e-governance is properly studied and measures taken to improve the situation. In this paper the citizen's perception of e-governance is studied empirically. Based on the response to a structured questionnaire administered to 400 citizens approaching e-seva centers, a statistical study on their perception using Pearson Correlation is made, Chi-Square Test for goodness of fit is conducted and relevant conclusions drawn. The process of sampling is attempted to be done on a quasi-random basis to ensure that the sample is as representative as the population seeking the services to minimize sampling errors.
\end{abstract}

Index-terms--e-governance, G2C, Citizen's perception, Pearson Correlation

\section{INTRODUCTION}

The infusion of technology in every field has always been providing more than commensurate returns. It is undoubted and undeniable fact that technology always brings efficiency, cost reduction, easier replication and better quality and transparency in any process where it is applied. Even the orthodox antediluvian, who romanticizes old way of life and living, would have to admit that technology is value neutral and it is the human nature that makes it double edged sword. The automation in all spheres is enabled mainly through technology. In the earlier stages of technological development, it was merely viewed as a tool for better manufacturing. It is now more than evident that the technology has made heavy inroads into service sectors and the delivery of any service is made better and superior in quality with technology component. From the citizen's perspective, Government is one of the important service delivery institutions-- more so, in modern welfare oriented democratic government set ups. Technology seems to have invaded this domain too and had brought about considerable benefit. EGovernance is something which is keenly embraced by various governments in the world to varying degrees.

\section{E-GOVERNANCE CLASFICATION}

The idea of e-Government can be classified into four categories- G2C,G2B,G2G, and G2E. This classification is based on differences in nature of interactions that different type of stakeholders have with the government.

2.1 GOVERNMENT TO CITIZEN $(G 2 C)$ :This classification refers to the Information and Communication Technology interface between the government and citizens. A G2C service expands the availability and accessibility of the government to an anytime anywhere more. This gives citizens the choice of when to interact with the government -24 hours a day, 7 days a week; from where to interact with the government- service centre, unattended kiosk or from the comfort of one's home; and how to interact--though internet, fax, telephone, email, face to face etc. In terms of frequency of interaction this is one of the important classifications as there is large volume of interactions in term of numbers. In a democracy where people decide as to who should rule them, the way G2C functions is very crucial, as the service is directed to an 
important stake holders. The stake holders collectively are in a position to change the government and a

government sensitive to the needs of the people should endeavor to make this service as efficient as possible. Being the instrument of an important interface, there is no denying the fact this requires constant attention and innovation. That is the reason why this particular service is taken up for specific study in this article and a survey of 400 citizens approaching three e -seva centers at Hyderabad is conducted.

2.2 GOVERNMENT TO BUSINESS G2B: This category of ICT enabled service helps the business communityproviders of goods and services- to seamlessly interact with the government. There are number of areas requiring government clearance by business community and often this involves clearance from various departments of the government.

2.3 GOVERNMENT TO GOVERNEMNT G2G:This kind of ICT enabled interaction takes place within the sphere of the government. G2G can be horizontal i.e. between different government agencies or vertical i.e. between national, state and local government agencies. In the context of our country, there are large number of state governments and local bodies. The set up is essentially federal and there is good deal of communication in order that there is a well coordinated effort. For smooth coordination and functioning of governments on truly federal basis as intended by constitution makers of India, it is equally important that the interment of $\mathrm{G} 2 \mathrm{G}$ interface functions without any hitch

2.4 SIMILARY GOVERNEMNT TO EMPLOYEES G2E: refers to the delivery of services by the Government to its employees. These types of services primarily relate to human resource areas.

\section{METHODOLOGY}

A structured questionnaire tested for statistical reliability was administered to 400 citizens. The citizens were chosen at random (essentially known as mall intercept method). The nature of arrival rate of the individuals at e-seva Center and their demographic profile is unknown and cannot be predetermined. At any point of time, when survey is undertaken at the e seva center, as the arrival of citizens is unknown before hand and as they do not follow an expected pattern, the sample can be considered random. The survey was done at three e seva centers chosen at random at Hyderabad. We have therefore, two stages sampling process-first in terms of sampling of the center and them sampling of respondents visiting the center. The questionnaire administered to citizens consists of 11 questions with a few questions intended to get the demographic information of the respondents. The questions are all close- ended in nature with options for responses indicated in the question itself. The last question is designed such that it makes the respondents to rank the various attributes of the e-seva center already considered in the order of priority for success of the automation project as a whole as perceived by the respondents. The complete responses received from 363 citizens were analyzed statistically. The rate of return of filled in questionnaire was $90.75 \%$ which can be considered as fairly good rate of return of responses for such kind of surveys .

\section{RESEARCH HYPOTHESIS}

H1. The usefulness of a $\mathrm{G} 2 \mathrm{C}$ e governance project is associated with the fulfillment of expectations of the citizens.

HO: Null Hypothesis:The usefulness of a G2C egovernance project is independent of the fulfillment of expectations of the citizen.

\section{CITIZEN'S SURVEY RESPONSE CODE CONVERSION:}

To study the relationship between variables of interest, the responses obtained from the 11 item questionnaire was converted from 4 point scale to dichotomous responses. The table 1 gives the citizen response code and the relevant conversion taken for data analysis.

\section{CORRELATION ANALYSIS}

The data obtained from citizen questionnaire was subjected to Pearson Correlation analysis Table. 2 for the following parameters:

1. Usefulness of e Seva project.

2. Satisfaction of service given by Operator

3. Overall satisfaction from the Center

4. Number of visits to the Center.

5. Distance of the Center from home. 
TABLE. I

CITIZEN SURVEY RESPNSE CODE CONVERSION

\begin{tabular}{|c|c|c|}
\hline $\begin{array}{l}\text { Description } \\
\text { of variable }\end{array}$ & Response code & Converted code \\
\hline $\begin{array}{l}\text { Variable } \\
\text { related to } \\
\text { awareness } \\
\text { of services } \\
\text { available at } \\
\text { the center }\end{array}$ & $\begin{array}{l}\text { 1. no idea } \\
\text { 2. somewhat aware } \\
\text { 3. reasonably aware } \\
\text { 4. well aware }\end{array}$ & $\begin{array}{l}0 \text { ( No idea) if } \\
\text { response code is } \\
\text { either } 1 \text { or } 2 . . \\
1 \text { (Well aware) if } \\
\text { response code is } \\
\text { either } 3 \text { or } 4 .\end{array}$ \\
\hline $\begin{array}{l}\text { Variable } \\
\text { related to } \\
\text { distance } \\
\text { from the } \\
\text { center }\end{array}$ & $\begin{array}{l}\text { 1. less than } 1 \mathrm{~km} \text {. } \\
\text { 2. } 1 \text { to } 3 \mathrm{~km} \\
\text { 3. } 4 \text { to } 5 \mathrm{~km} \\
\text { 4. } 6 \text { to } 10 \mathrm{~km} \\
\text { 5. more than } 10 \mathrm{~km}\end{array}$ & $\begin{array}{l}0 \text { (less than } 3 \mathrm{~km} \text { ) if } \\
\text { response code is } \\
\text { either } 1 \text { or } 2 . \\
1 \text { (more than } 3 \mathrm{~km} \text { ), } \\
\text { if response code is } \\
\text { either } 3,4 \text { or } 5 .\end{array}$ \\
\hline $\begin{array}{l}\text { Variable } \\
\text { related to } \\
\text { usefulness } \\
\text { of center }\end{array}$ & $\begin{array}{l}\text { 1. not at all useful } \\
\text { 2. slightly useful } \\
\text { 3. quite useful } \\
\text { 4. very useful }\end{array}$ & $\begin{array}{l}0 \text { ( not useful) if } \\
\text { response code is } \\
\text { either } 1 \text { or } 2 \text {. } \\
1 \text { (very useful if } \\
\text { response code is } \\
\text { either } 3 \text { or } 4 .\end{array}$ \\
\hline $\begin{array}{l}\text { Variable } \\
\text { related to } \\
\text { services of } \\
\text { operator }\end{array}$ & $\begin{array}{l}\text { 1. not at all satisfied } \\
\text { 2. low satisfaction } \\
\text { 3. neither satisfied } \\
\text { nor dissatisfied } \\
\text { 4. very satisfied }\end{array}$ & $\begin{array}{l}0 \text { ( not satisfied) if } \\
\text { response code is } \\
\text { either } 1 \text { or } 2 . \\
1 \text { (very satisfied) if } \\
\text { response code is } \\
\text { either } 1 \text { or } 2 .\end{array}$ \\
\hline $\begin{array}{l}\text { Variable } \\
\text { related to } \\
\text { overall } \\
\text { satisfaction }\end{array}$ & $\begin{array}{l}\text { 1. not at all satisfied } \\
\text { 2. low satisfaction } \\
\text { 3. neither satisfied } \\
\text { nor dissatisfied } \\
\text { 4. very satisfied }\end{array}$ & $\begin{array}{l}0 \text { ( not satisfied), if } \\
\text { response code is } \\
\text { either } 1 \text { or } 2 . \\
1 \text { ( very satisfied) if } \\
\text { response code is } \\
\text { either } 3 \text { or } 4\end{array}$ \\
\hline $\begin{array}{l}\text { Variable } \\
\text { related to } \\
\text { gender }\end{array}$ & $\begin{array}{l}\text { 1. male } \\
\text { 2. female }\end{array}$ & $\begin{array}{l}1 \text { for male } \\
\text { 2. for female }\end{array}$ \\
\hline
\end{tabular}

\begin{tabular}{|c|c|c|c|c|c|c|}
\hline \multicolumn{7}{|c|}{ PEARSON CORRELATION MATRIX } \\
\hline parameter & $\begin{array}{l}\text { Statistical } \\
\text { Attribute }\end{array}$ & \begin{tabular}{|l} 
Usefulne \\
ss of \\
E-seva \\
Center
\end{tabular} & $\begin{array}{l}\text { Satisfaction } \\
\text { Of service- } \\
\text { Operator }\end{array}$ & \begin{tabular}{|l|} 
Overall \\
satisfaction \\
From the \\
Center
\end{tabular} & \begin{tabular}{|l|} 
No of \\
Visits \\
to the \\
Center
\end{tabular} & \begin{tabular}{|l|} 
Distance \\
of the \\
Center \\
from \\
home \\
\end{tabular} \\
\hline \multirow[t]{2}{*}{\begin{tabular}{|l|} 
Usefulness \\
of \\
e-seva \\
Center \\
\end{tabular}} & $\begin{array}{l}\text { Pearson } \\
\text { Correlation }\end{array}$ & 1 & $0.409^{\star \star}$ & $0.356^{\star \star}$ & 0.85 & $.146^{\star \star}$ \\
\hline & $\begin{array}{l}\text { Significance } \\
2 \text { tailed }\end{array}$ & & 0.000 & 0.000 & .107 & .005 \\
\hline \multirow[t]{2}{*}{\begin{tabular}{|l|} 
Satisfaction \\
of \\
Service \\
given \\
By operator \\
\end{tabular}} & $\begin{array}{l}\text { Pearson } \\
\text { Correlation }\end{array}$ & $0.409^{* *}$ & 1 & $0.528^{\star \star}$ & 0.049 & .029 \\
\hline & $\begin{array}{l}\text { Significance } \\
2 \text { tailed }\end{array}$ & 0.000 & & 0.000 & .355 & .586 \\
\hline \multirow[t]{2}{*}{$\begin{array}{l}\text { Overall } \\
\text { satisfaction } \\
\text { from } \\
\text { The center } \\
\end{array}$} & $\begin{array}{l}\text { Pearson } \\
\text { correlation }\end{array}$ & $.356^{\star \star}$ & $.528^{\star *}$ & 1 & 0.036 & -.014 \\
\hline & \begin{tabular}{|l|}
$\begin{array}{l}\text { Significance } \\
\text { 2tailed }\end{array}$ \\
\end{tabular} & 0.000 & 0.000 & & .491 & .797 \\
\hline \multirow[t]{2}{*}{\begin{tabular}{|l|} 
Number of \\
visits to the \\
Center \\
\end{tabular}} & \begin{tabular}{|l} 
Pearson \\
Correlation
\end{tabular} & 0.085 & .049 & .036 & 1 & $.235^{* *}$ \\
\hline & $\begin{array}{l}\text { Significance } \\
\text { 2tailed }\end{array}$ & .107 & .355 & .491 & & .000 \\
\hline \multirow[t]{2}{*}{$\begin{array}{l}\text { Distance of } \\
\text { the Center } \\
\text { from home }\end{array}$} & \begin{tabular}{|l} 
Pearson \\
Correlation
\end{tabular} & $.146^{\star \star}$ & 0.029 & -.014 & $.235^{\star \star}$ & 1 \\
\hline & $\begin{array}{l}\text { Significance } \\
\text { 2tailed }\end{array}$ & .005 & .586 & .797 & .000 & \\
\hline
\end{tabular}

The analysis of the correlation matrix indicates that a few of the observed matrix were strong. The positive relationship was observed between "satisfaction of service given by the operator and "the overall satisfaction experienced by the citizen from the center" ( $\mathrm{r}=0.528)$. This indicates that the quality of service given by the operator contributes to the overall satisfaction of the citizen from the centre. Another positive correlation was established between "usefulness of E seva center and "satisfactory of service given by operator" ( $\mathrm{r}=0.356)$.

The relation between "distance of center from home" and "number of visits to the center" $(\mathrm{r}=.235)$, and between "distance of center from home" and "usefulness of e seva Project" ( $r=0.146)$ though positive in both cases, is weak in nature. Another important correlation observed is the negative correlation between the "distance of center from home" and "overall satisfaction from the center" ( $\mathrm{r}=-$ ve0.014). This observation is important from the manner in which the "distance variable was coded in the Citizen Survey Response.

The survey did not intend to cover demographic attributes. However, it was found that there is no significant difference between the prioritized expectation of male and female citizens (Spearman Rank Correlation coefficient=0.7) Hence, the perception of male or female citizens may be considered as overall perception of citizens in general. However, the overall satisfaction of the citizen from the $\mathrm{G} 2 \mathrm{C}$ project contributes to the overall usefulness of the project.

The statistical analysis reveals that the overall usefulness of the project depends on the following factors (1) Satisfaction of service given by Operator (2) Overall satisfaction from the center (3) number of visits to the center. The analysis also reveals that the "distance of the center from home of a citizen" has a direct impact on the "overall satisfaction from the center".

\section{CHI-SUARE TEST FOR GOODNESS OF FIT}

The results of Chi-Square analysis for Goodness of Fit conducted are tabulated as shown in Table. 3 and the inferences are drawn as under.

TABLE III

TEST STATISTICS

\begin{tabular}{|c|c|c|c|c|}
\hline & $\begin{array}{c}\text { Usefulness } \\
\text { of center }\end{array}$ & $\begin{array}{c}\text { Operator } \\
\text { level } \\
\text { satisfaction }\end{array}$ & $\begin{array}{c}\text { Overall } \\
\text { satisfaction }\end{array}$ & $\begin{array}{c}\text { Distance } \\
\text { of center } \\
\text { from } \\
\text { home }\end{array}$ \\
\hline Chi-Square & 287.408 & 236.499 & 208.333 & 324.102 \\
\hline Df & 1 & 1 & 1 & 1 \\
\hline Significance & .000 & .000 & .000 & .000 \\
\hline
\end{tabular}

The Chi-Square statistics (Table-2) 287.408,236.499,208.333 and 324.102 for usefulness, operator level satisfaction, overall satisfaction and distance with its small significance level, p less that 0.001 for all the variables indicate that a normal distribution provides a Good Fit to the observed data. Thus we can reject the null hypothesis and test results support the research hypothesis that the usefulness of a $\mathrm{G} 2 \mathrm{C}$ e-Governance project is associated with the fulfillment of expectations of the citizens. 


\section{CONCLUSION}

One of the research objectives was to study citizen expectations and performance of the e-Governance project. The data analysis of the citizen survey has given sufficient understanding on their expectations and performance of the project from citizen perspective. The analysis reveals that the citizens have different expectations across the age group, gender or occupational background of citizens. The importance of a similar expectation also differs amongst citizens who have visited the centers to avail government services. The statistical data analysis validates the research hypothesis that citizens find the e-Government project useful if their expectations are met by the project.

\section{REFERENCES}

[1] Ahmed Al-Omari and HusseinAl-Omar, E- Government Readiness Assessment Model, Journal of Computer Science 2(11): 841-845,2006

[2] Andria Di Maio, David McCluire: Using the E-Government Assessment Questionnaire

[3] Bata KDey. E Governance in India: Problems, Challenges and Opportunities - A Future's Vision

[4] Department of Information Technology, Ministry of Communications \& IT Government of India, Impact Assessment Study of e-Governance projects in Indian Report, 2007

[5] Evaluating e-Governemnt: M.P Gupta, Jaijit Bhattacharya, Ashok Agarwal, published in Governance Case Studies, Ashok Agarwal, University press, 2007

[6] Piyush Gupta, Challenges and Issues in e-Government Project Assessment, paper presented and published as part of the ICEGOV 2007, Dec10-13, 2007 Macao, China

[7] Piyush Gupta, R.K. Bagga, Book edited "Compendium of Project initiatives in India”, University Press ,2008. 